RATIONAl EXPECTATIONS: RETROSPECT AND PROSPECT

A PANEL DISCUSSION WITH

MICHAEL LOVELL

ROBERT LUCAS

DALE MORTENSEN

ROBERT SHILLER

NEIL WALLACE

MODERATED BY

KEVIN HOOVER

WARREN YOUNG

CHOPE WORKING PAPER NO. 2011-10

30 MAY 2011

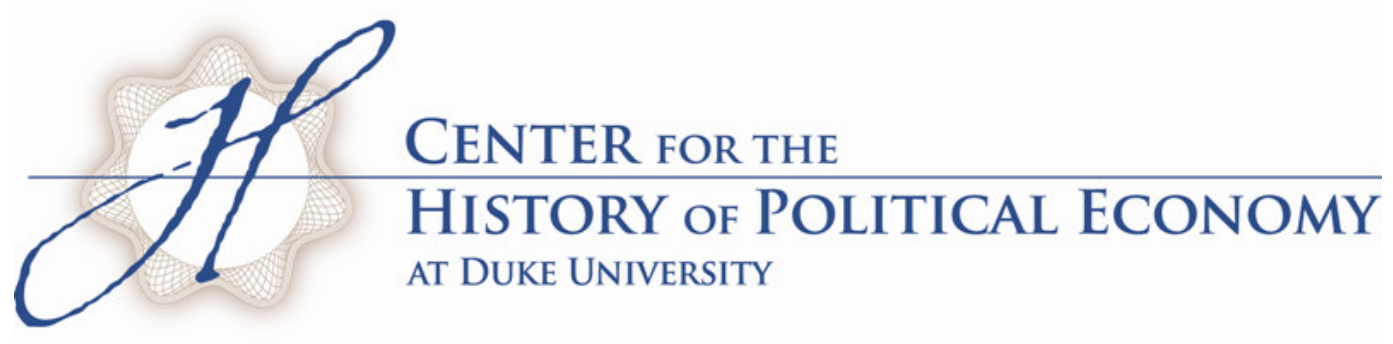




\title{
Rational Expectations: Retrospect and Prospect
}

\author{
A Panel Discussion with
}

Michael Lovell

Robert Lucas

Dale Mortensen

Robert Shiller

Neil Wallace

\section{Moderated by}

Kevin Hoover $\dagger$

Warren Young*

30 May 2011

$\dagger$ Department of Economics and Department of Philosophy, Duke University. Address:

Box 90097, Durham, NC 27278, U.S.A. E-mail kd.hoover@duke.edu

*Department of Economics, Bar Ilan University. Address: Department of Economics, Bar Ilan University, Ramat Gan 52900, Israel. E-mail: youngwprof@yahoo.com 


\section{Abstract}

\section{of}

\section{Rational Expectations: Retrospect and Prospect}

The transcript of a panel discussion marking the fiftieth anniversary of John Muth's "Rational Expectations and the Theory of Price Movements" (Econometrica 1961). The panel consists of Michael Lovell, Robert Lucas, Dale Mortensen, Robert Shiller, and Neil Wallace. The discussion is moderated by Kevin Hoover and Warren Young. The panel touches on a wide variety of issues related to the rational-expectations hypothesis, including: its history, starting with Muth's work at Carnegie Tech; its methodological role; applications to policy; its relationship to behavioral economics; its role in the recent financial crisis; and its likely future.

JEL Codes: B22, B31, B26, E17

Keywords: rational expectations, John F. Muth, macroeconomics, dynamics, macroeconomic policy, behavioral economics, efficient markets 


\section{Rational Expectations: Retrospect and Prospect:}

\section{A Panel Discussion with Michael Lovell, Robert Lucas, Dale Mortensen, Robert Shiller and Neil Wallace, Moderated by Kevin Hoover and Warren Young}

The panel discussion was held in a session sponsored by the History of Economics Society at the Allied Social Sciences Association (ASSA) meetings in the Capitol 1 Room of the Hyatt Regency Hotel in Denver, Colorado on 7 January 2011. ${ }^{1}$

KEVIN D. HOOVER: Good afternoon. Let me welcome you to the session Rational Expectations: Retrospect and Prospect on the 50 th anniversary of John Muth's "Rational Expectations and the Theory of Price Movements" [1961].

In 1961, John Muth published "Rational Expectations and the Theory of Price Movements" in Econometrica. Fifteen years later, it was commonplace to speak of a rational expectations revolution. And within another fifteen years, rational expectations had been fully integrated into macroeconomics. This session marks the $50^{\text {th }}$ anniversary of Muth's paper.

The oldest reference in the JSTOR journal archive to the term "rational expectations" comes from 1780 [Blizard and Warner 1780]. It had to do with expectations of success of surgical procedure rather than anything economic. The earliest use in an economics journal is from 1923, but the sense is hardly any different than it was in the medical article [Price 1923, p. 361]. It refers to an expectation based solidly on facts and evidence. T.W. Schultz, in an agricultural economics journal in 1939, used the term in a similar sense. He suggested that one might, "wish to help the farmer arrive at more rational expectations before he has allocated or reallocated his

\footnotetext{
${ }^{1}$ Material in curly brackets records interventions and audience reactions in the course of the discussion; material in square brackets are subsequent editorial interpolations.
} 
stream of assets into the form of more or less fixed resources.” [Schultz 1939, p. 582]

But Schultz went on to introduce something new. He wrote,

Once his assets are committed the original expectations are only of secondary importance; for the problem at a later date becomes one of how much can he salvage in view of his first errors. This brings in the whole problem of risk and uncertainty which we are leaving for another time. [p. 582]

Writing in 1951 on the term structure of interest rates, Joan Robinson noted the no-arbitrage condition that allows long rates to be expressed as expectations of short rates and short rates as expectations of long rates. She continued: "But all this means is that rational expectations must be self-consistent.”[Robinson 1951, p. 102]. In 1958, Thomas Schelling used the term rational expectations to describe fully-shared expectations of the outcome of a game [Schelling 1958, p. 253].

These various precursors come closer to our modern usage, but none quite captures Muth's definitions. He wrote that rational

expectations, since they are informed predictions of future events, are essentially the same as the predictions of the relevant economic theory.

The hypothesis can be rephrased a little more precisely as follows: that expectations of firms (or, more generally, the subjective probability distribution of outcomes) tend to be distributed, for the same information set, about the prediction of the theory (or the "objective" probability distributions of outcomes).

The hypothesis asserts three things: (1) Information is scarce, and the economic system generally does not waste it. (2) The way expectations are formed depends specifically on the structure of the relevant system describing the economy. (3) A "public prediction," in the sense of Grunberg and Modigliani, will have no substantial effect on the operation of the economic system (unless it is based on inside information). [Muth 1961, p. 316]

Muth wrote from a microeconomic perspective and his paper was treated with respect, but with no great excitement. A search of JSTOR for the decade 1960-1969 for the 
terms "rational expectations" and "Muth" turns up 29 citations ("rational expectations" without Muth adds 9 more). But then macroeconomists discovered rational expectations. In the seventies, "rational expectations" and "Muth" are cited 171 times; in the eighties, 324 times; and in the nineties, 141 times. The seventies and eighties were thus a boomlet for Muth. But rational expectations was rapidly detached from its founder and experienced a boom multiple times larger: a search on "rational expectations" that doesn't condition on "Muth" turns up 509 citations in the seventies, 3,150 in the eighties, and 2,854 in the nineties. Rational expectations by the $1990 \mathrm{~s}$ was a standard tool of economists, and its origins were hardly noted by younger generation.

Our purpose today is, in part, to rectify that - both to remember and to reflect. We have assembled a distinguished panel of economists who were witnesses to the rise and integration of rational expectations into economics.

Our format today will be one of a group interview or witness seminar. Warren Young and I will take turns posing questions, sometimes to particular panelists and sometimes to the group. In all cases, we invite the panelists to chime in with whatever they think relevant on important points or things that we may be missing. We are looking both to understand the origins and growth of rational expectations in economics, its pluses and minuses, the battles fought over it, and to consider what place it will have in the economics of the future.

I now turn the floor over to Warren Young for the first question. 
WARREN YOUNG: The first question involves Muth and Carnegie Tech and the direct impact of the Carnegie context. ${ }^{2}$ How well did you know Muth and what influence did he have on you? Did you learn about rational expectations directly from Muth? If not, how did you learn about it? Some of you didn't know Muth personally. Some of you, especially in Bob Shiller's case, were students of Franco Modigliani, who was also at Carnegie. So the question is, where did you first encounter Muth and where did you first encounter rational expectations?

MICHAEL LOVELL: I first really got to know Jack Muth in 1962-63 when he was a visiting scholar at the Yale's Cowles Foundation. We talked at length about rational expectations and compared it with a related concept, namely the concept of "implicit expectations," which had been developed by Edwin Mills in his study of inventory behavior. And later, in the following year, I moved to Carnegie Mellon, getting there in the same year that Bob Lucas did. Jack was, of course, already there, as was Dale Mortensen. And when I got to Carnegie Mellon, I had just received an opportunity to study actual expectations data for 135 United States manufacturing firms in a panel stretching over several years. So I talked to Jack about how I should analyze the data, and he was extremely helpful. And indeed I must say that while I have been blessed with great professors, brilliant students and tremendous colleagues, no one was more helpful than Jack. He laid out the type of tests that should be run on the data. Muth strongly supported empirical testing of rational expectations. So those are my initial contacts with Jack Muth and the concept of rational expectations.

\footnotetext{
${ }^{2}$ The Carnegie Institute of Technology merged with the Mellon Institute of Industrial Research in 1967 to form Carnegie Mellon University.
} 
ROBERT LUCAS: I came to GSIA in 1963 from Chicago. I knew Jack's paper, which was famous. I probably hadn’t read it, but I knew about it. Zvi Griliches had told me, "pay attention to Jack Muth. He's a person you could learn something from." I think that was about as good as any advice I got during my career. I taught econometrics that was a plum for me to teach $\mathrm{Ph} . \mathrm{D}$ econometrics. It was a two-course sequence, and Jack was the other teacher. So we talked a lot. Jack was a skier, so I filled in for a week in March while he was in Colorado. He then left me detailed instructions as to what to do, so it was easy. Then when he came back, he gave a couple lectures to my class, which I sat in on. He was a smart guy. At some point I'm going to quarrel with Kevin's introduction: we don't want to go back to all the people who used the words "rational" and "expectations," back to Adam Smith. Muth's idea of rational expectations - whether the term was a good one or not $-\ldots$ no one had said anything like this before. It was his simultaneous determination of people's behavior which produced a time series and a time series which led people to form expectations that affected their behavior. It's that simultaneity that neither the statisticians nor the economists of the day had ... and Jack had it.

DALE MORTENSEN: I'm the student of the bunch, as was already revealed. When these two arrived, I was a student starting to think about a thesis. Before they arrived, I obviously was badly advised, because I never took Jack's course. I did take Bob's though . . . my only econometric course (that's a little joke between us). \{laughter Where I did learn about it? Or, at least, where was I introduced to it? I am not exactly sure what year, but Bob set up a workshop on rational expectations (on expectations, at least) ... I think my last year. (You don't remember that, Bob?) 
LUCAS: Was that me or Mike?

MORTENSEN: Both of you. That's where I was first introduced to it, but it didn't sink in really until later when I started worrying about the problem within my own modeling of equilibrium models. Oh, I should add, though, there is a book called Holt, Muth, Modigliani, and Simon, and I was brought up on that. So in that sense, certainly in that context, I was introduced to it fully. ${ }^{3}$

ROBERT SHILLER: If I might do the unthinkable and bring up earlier people, I think we all need to remember the time-series-analysis people. What comes to my memory first is [George] Box and [Gwilym] Jenkins' book called Time Series Analysis for Forecasting and Control [1970], which coined the ARIMA [autoregressive integrated moving average] model, and that was the core idea, I think. I also remember meeting Herman Wold, who, again, was an econometrician and invented the Wold decomposition, that every time series can be decomposed into a moving average of i.i.d [identical independently distributed] terms. So, I think that Jack Muth was realizing the impact and the importance of these models. As for a little personal history, Albert Ando was my friend at Penn [University of Pennsylvania]. He was his [Muth's] roommate in graduate school, and he recalled the conversations they had.

HOOVER: The volume of Holt, Modigliani, Muth, and Simon has been mentioned. Muth was at Carnegie and the work on expectations in the fifties was going on at Carnegie. Does anyone on the panel want to comment on the environment at Carnegie or the environment of the expectations research program running up to Muth's rational-expectations paper and how the environment at Carnegie fed into or

\footnotetext{
${ }^{3}$ Holt et al. (1960)
} 
influenced, characterized or gave a background to what Muth's paper was attempting to do?

LUCAS: Modigliani started working on studying expectations data when he was at the University of Illinois, and he brought this project with him when he came to Carnegie. Of course, he was a senior coauthor to this Holt, Modigliani, Muth, and Simon book. Jack cites a paper by Modigliani and Marty Weingartner [H. Martin Weingartner], who was another student of the vintage of Albert Ando and Muth. So, expectations came into the Holt, Modigliani, Muth, Simon book because they were talking about inventory management. So, part of the thing was, given a pattern of expected future sales, what would you do with production and employment? And then the other pattern was how do you get forecasts of future sales? Those guys were definitely into time series. They probably weren't as good at it as Box and Jenkins, but that was a key part of that Holt, Modigliani, Muth, Simon book. One of things that got Jack going was that people were using exponential smoothing - like Friedman and [Phillip] Cagan and [Marc] Nerlove did - as a forecasting rule. And Jack asked the question what would a time series have to look like for exponential smoothing to be the optimum forecast rule? And he solved that: he got the connection between the signal and the noise, the variances of the components of the time series, and the weighting formula of the distributed lag. Now, once he got that, then I think it opens the door to what Bob Shiller is saying: that we can do that for any time series; it doesn't have to be a combination of random walk and i.i.d. shocks. We can characterize and describe and forecast time series much more generally, just as Box and Jenkins did. But I think 
Muth opened the door for incorporating this idea into economic. That was a big step forward.

HOOVER: Would you say anything about the social atmosphere or the collegial interactions at Carnegie? Did they matter much, or is that something we ought not to be thinking about when we're writing the history of rational expectations?

LUCAS: I loved the place. Jack was an extremely shy person, a socially awkward person. Even if you were friends with him, you couldn't really argue with him. It was awkward to talk to him. He was too easily pushed around even though he knew twice as much as you did. But I don't think that was the atmosphere at Carnegie, I think that was just Jack. The rest of us talked all the time.

MORTENSEN: Well again, as a student, maybe I should comment a little on that. The level of interaction was very high. There were very many discussions going on, and there weren't many students, so we got pulled into it very early. But one of the things I certainly remember and affected my career: dynamics was in the air . . . in every way ... dynamic optimization models ... we talked a little bit about time series. But, of course, the whole real point of Muth's contribution is to go well beyond time series. It's an issue of how to bring together, possibly, the theory and time-series econometrics in a sensible way.

HOOVER: Does anyone else want to comment about this issue of either Carnegie or the background of rational expectations?

LUCAS: At some point, I want to talk about Herb Simon.

HOOVER: Go right ahead. 
LUCAS: There's a strange paragraph ...

\section{MORTENSEN: yes ...}

LUCAS: . . . on the second page of Jack's 1961 paper. Herb Simon was the god of the Graduate School of Industrial Administration. He was a great intellectual. He had a huge effect on all of us - and especially Jack. But Jack says, "It is sometimes argued that sometimes the assumption of rationality in economics leads to theories inconsistent with, or inadequate to explain, observed phenomena, especially changes over time" [Muth 1961, p. 316]. Then he says "e.g. Simon" and cites a paper. Then he says "Our hypothesis is based on exactly the opposite point of view" [Muth 1960, p. 316]. So, this is a shy graduate student taking on, not just a professor, but the most respected professor, who was and a huge influence on Jack for the rest of his life.

HOOVER: Anyone else on this topic?

NEIL WALLACE: Dale mentioned that dynamics was in the air when he was a graduate student at Carnegie, and I'd just like to reflect a little about dynamics and non dynamics in economics. I was a graduate student in the University of Chicago from '60 to '63, and I had heard about - or maybe read - Muth's paper. I vaguely recall his dictum: "model the agents as if they know the model." Maybe later, we will discuss whether that dictum can be reconciled with discovering a model. But anyway, in some sense dynamics gets introduced in economics in the late $19^{\text {th }}$ century. Irving Fisher is, of course, a major figure. He said rather than "apples" and "oranges" on the axes, put "date-1 good" and "date-2 good." That's a huge insight, because it says look at the entire time path as an object. It's only two dates, but it's a time path. Lucas and I were in Milton Friedman's price theory course in my first year there: two quarters of 
price theory - supposedly general equilibrium theory, but not very well done.

Friedman knew how to put "date-1 good" on one axis and "date-2 good" on the other axis, but he was not at home with the idea of dated commodities. And when he tried, at the end of the course, to teach us a little capital theory, it was a mess. Somehow, by default - because of bad training and laziness on my own part - I became a macroeconomist. And it was hugely painful to apply this Irving-Fisher vision in a serious way. In fact, the first paper that I read, which was a serious intertemporal model, was Bob's "Expectations and the Neutrality of Money" [Lucas 1972a]. And, that is a painful way to be introduced to intertemporal models. But that was the state of macro at that time.

HOOVER: Maybe I can keep you there for a second, because you might want to respond to the next question. I think that you raise some issues about conceptualization, and we're interested in how people should think about the conceptualization of rational expectations. I read Muth's definition from his paper; but in the follow-up over the last fifty years people have tried to gloss rational expectations in various ways: as model consistent expectations; as the notion that the agent knows the true model of the economy and forms expectations based on it; as the notion that expectations are not systematically biased; as a notion that agents learn in an efficient and unbiased way from their expectational mistakes; as a notion that expectations are the optimizing solution to the likelihood function. So there are lots of different ways that people have tried to let us know what is meant by rational expectations. The question, then, for all of the panel is, apart from Muth's paper and 
the definition that one finds there, what do you regard as the most useful way for us to characterize rational expectations?

WALLACE: To me, it's an equilibrium concept; and, when you do economics these days, if you are not using it, then you have to say why. But, in some ways, the big innovation was doing dynamics using that concept. That's the innovation. We've always done rational expectations, even in the static competitive model. Equilibrium demand of a person is evaluated at the equilibrium price. The person doesn't think he or she is trading at 10 when the equilibrium price is 5 . So it's an equilibrium concept and it's used in all of game theory.

LUCAS: But we're not all using the same terminology. So Kreps and Wilson could talk about sequential equilibrium. Game theory assumed rational expectations, but without the terminology - I was citing [David] Kreps and [Robert] Wilson's paper on equilibrium, which was kind of a basic contribution to dynamic games. I don't know if those guys know about rational expectations. They certainly don't mention it anywhere in their paper.

SHILLER: So, we keep talking about this core idea that was original to Muth, that it's essential to macroeconomics that we have expectations and that our actions depend on those expectations. Everyone knew that. But the idea of putting together a model that was internally consistent was a brand new idea. And it often amazes me how long it takes for seemingly simple ideas to take root. It might seem obvious. I was saying that once you read Box and Jenkins and are building models, why isn't that obvious? But it's not obvious. If I can just interject, another example that amazes me about what's not obvious. (This is from finance, if you'll excuse me.) Another 
breakthrough idea: in 1952 Harry Markowitz wrote an article in the Journal of Finance that said we have to represent expected return and risk as part of a tradeoff [Markowitz 1952]. He said you can't talk about maximizing the expected return on a portfolio - because that's meaningless - or minimizing the variance. It has to be that you define a tradeoff and that people have preferences about where they would place themselves on this tradeoff. He's absolutely right, but what I was trying to understand was how people could not have understood that. And I went back, and I did the same kind of research. I found that you could go all the way back to the beginning of the $19^{\text {th }}$ century and you will find people warning you that you have to worry about both risk and variance. But nobody put it together in the way that you could do formalistic math models. So that was Markowitz, he got the Nobel Prize for that. Muth never got it - right?

MORTENSEN: Right ...

SHILLER: He didn't live long enough; he probably would have gotten it. It's just curious to me, and I think maybe it has something to do with Muth's personality, which you were describing as introverted and awkward, maybe. He somehow had an independent streak that let him think of things that were almost there but not there yet.

LOVELL: In 1962-63, when Jack Muth was visiting at Yale, he was concerned with the task of writing a book review of Edwin Mills' book on inventories [Mills 1962]. Edwin Mills had advanced the concept of "implicit expectations." Mills wanted to use the concept of expectations in his empirical study of inventory behavior based on data for individual firms. Mills did not have expectations data, so instead he used the actual realization as a proxy for the expectation, and he made the assumption that the 
forecast errors were randomly distributed about the realization. This meant that the implicit expectations have a larger variance than the actual variable being predicted, which was sales in his case. It was also an assumption of convenience, because it meant that Mills could use sales as an explanatory variable in his regressions without running into the bias that arises when the observational errors are correlated with the actual realization. That's in contrast to Muth's concept of rational expectations, which had the error term distributed the other way. To illustrate Muth's approach, suppose you have a regression model which correctly describes the economy -after you use that model to make your prediction, nature draws a random number out of her urn when she generates the actual data that you forecasted; and, as a result, the actual realization has a bigger variance than the forecasts. And so, this was the issue that Muth was addressing in writing his review. But he didn't just write a review; he got hold of all of the data that Mills had used in his book. He planned to rerun the regressions, but transformed to make sales the dependent variable, as required for consistent estimates under the assumption of rational expectations. But first he reran all the regressions that Mills had run - and they didn't pan out. Here was the published book and here were the results that Muth was getting, and none of the regressions jibed correctly. Well, this was not in the days of modern computers. No, this was in a day when you put your data on IBM cards (one observation per card), and if your research assistant dropped them on the way to the mainframe computer on the other side of the campus, you could be in deep trouble. So it's understandable how these things would happen. Mills in commenting on this - and I think it was an appropriate comment - said that none of the conclusions he reached in his book would 
be affected by the minor deviations between his fit and what the actual results should have been. I think this shows that Muth was a very conscientious and hardworking scholar who didn't take assignments lightly. But bogged down by Mills' erroneous estimates, Muth never actually finished the review.

MORTENSEN: I'd like to back off a little bit and talk maybe on the history of thought or the history of theoretical thought. Bob's already mentioned that rational expectations or some closely related concept is built into game theory. I mean it's there before; it's in the original formulation of game theory. And he also mentioned that the idea of rational expectations has a big impact on macroeconomics. So, I think we need to talk about that a little bit. Neil mentioned that he was taught that dynamics was simple: you just had two dimensions and you date them. Well, that's not the case. That's true provided that there's basically no uncertainty about anything anywhere. And of course the beautiful theoretical example of just dating the products is ArrowDebreu. But, formally, in Arrow-Debreu you have complete markets; you know all the prices at day zero. So, there's no uncertainty about what the prices are. Now, taking that idea into macroeconomics, it doesn't work, particularly if it's going to be real macroeconomics, because all prices are not set at date zero. There's just a basic incomplete markets problem. What Jack Muth did for macroeconomics was to say ... Well, all right, let me jump: In the 'sixties - I remember this very clearly - we talked about temporary equilibrium. Temporary equilibrium was an equilibrium now with expectations about the future - unspecified expectations of the future. There's some basic problems with that. I think Neil was right by pointing to Bob's paper, because that's what I used to teach my students as well, after I learned about it. If you're really 
going to deal with macroeconomic issues, you have to be somewhat explicit about what's going on in terms of disturbances in the economy. And once you're explicit about that, then it's natural to build onto that specification Muth's notion that agents know about what's going on in the model. I don't know whether that's the right thing to do - I have some real qualms about it - but, from the intellectual point of view, it is certainly the most satisfying way to do it.

YOUNG: We are going to shift gears a bit and go on to the reception and impact of rational expectations on the academic level and the policy level. Sargent and Wallace's [1971] earliest published work on rational expectations was grounded as much in Muth's 1960 paper, which rationalizes the use of distributed lag models as consistent with rational expectations, while Bob Lucas's is focused more on the natural-rate hypothesis, the Phillips curve, and the labor market. These are different paths, but did they have a common source? How much communication was there amongst the early proponents of rational expectations? Was there a degree of crossfertilization or was it an independent program or a cooperative program?

LUCAS: I can tell you about me and Tom and Neil. Muth's idea was that if you take a policy that changes the time series characteristics and some of the variables that you were trying to forecast, people are going to be changing in their forecast rule, and you better have a model that explains exactly how that change occurs. He says explicitly on page one of his paper, "It is a simultaneous equations issue." Now, how do you make this point? Well, just working out the rationalization of exponential smoothing doesn't do it. That's just a single microproblem. As Bob Shiller says, it's just a simple example that gets you started thinking about ARMA processes and so on. So, 
Jack, in his paper, goes into a long deal about the ... what do you call them? ... the negative root in the difference equation bouncing back and forth ... what do we call this thing? Everybody knows this but me ... \{Mortensen chuckles $\}$. . a difference equation ... cobweb! . . a difference equation with a negative root, so that people that want to talk about cycles, but don't want to spend a lot of time learning about complex variables, they fell on this cobweb cycle as a really cool way to talk about business cycles. Jack has a long critique of that: the evidence that people adduce; the idea that if it is a bad crop, prices go up and all the farmers plant huge amounts to get the high price, so that next year there's a glut and the price goes down. And the poor old farmers keep screwing up and keep making the same mistake over and over again. Jack worked this thing out with rational expectations - seriously compared his version to the standard version. It's an impressive thing, but it was really beating a dead horse. Nobody gave a damn about the cobweb model. Everybody knew it was a piece of junk. It was a textbook illustration. So, that was not enough to convince people that rational expectations was an important idea. You say "okay, Jack certainly makes the cobweb theory look silly;" but, you know, I thought it was silly before Jack came along. Now, then came the macro stuff: When Tom and Neil and I started plugging the same principles that Jack had advised into Keynesian models . . Jack didn't care about Keynesian economics, and it wouldn't have occurred to him to use that as an illustration, but it occurred to us. Neil and Tom took an IS-LM model and just changed the expectations and nothing else, and just showed how that seemingly modest change completely, radically alters the operating characteristics of the system. People noticed at that point. Now we were applying Jack's ideas to something that 
wasn't a straw man. It was something a lot of people had invested in, cared a lot about. It was helping to answer some real questions about macro policy, and his, Muth's, ideas start to really matter. There's no question that we got some undue credit for the basic concept, where what we had, I would say, was a more sexy implementation of an idea that Muth had offering a boring implementation of.

SHILLER: I have a question: I have absolutely no connection to Carnegie-Mellon, but I did go to graduate school at MIT [Massachusetts Institute of Technology]. Carnegie Mellon used to be Carnegie Institute of Technology. In my experience at MIT, another institute of technology, we were surrounded by scientists, and I kind of incorporated that in my thinking - I felt like a scientist too - and I just wonder if there is a broader sense like that at Carnegie Mellon Also, you were not in a regular business school in something different: ... it at Carnegie Tech it was called Industrial Management ...

LUCAS: and we didn't give an MBA; we gave an MS, a Master of Science.

MORTENSEN: That's because you had to have a math background to get in.

SHILLER: You had to have a math background to get in. So, there is something scientific behind the rational expectations revolution, and it comes from weather forecasters and oceanographers. . . The question is, is there a broader Carnegie culture that you can reminisce about, and where did it come from?

HOOVER: That is the question we were trying to ask earlier.

\footnotetext{
${ }^{4}$ In 1951 Carnegie Tech created an undergraduate program in "industrial management." Carnegie's business school was the Graduate School of Industrial Administration.
} 
MORTENSEN: I don't know. Being trained to build models, take models seriously, and apply models. That's what I got out of my experience. I don't know if that characterized it or not. Ask Bob. As a student, I was trained to create models, take models seriously, and apply them. And that was the milieu that I received.

LUCAS: Being a part of an engineering school and trying to hold your head up high when you were teaching business students, it did have an effect on all of us, for sure. The other thing that was so important in the 'fifties and 'sixties was operations research. The World War II generation brought a whole bunch of smart guys, like Abraham Wald and Friedman, whom we've already talked about,. . . I mean everybody into Washington to work on the war effort, and economists thought of all kinds of great stuff ... I guess that's what we always claim. We invented the convoy system . . . we basically won the war singlehandedly. \{laughter\}

MORTENSEN: Linear programming did it.

LUCAS: So then after the war, the military financed research on management and economics. The Holt, Modigliani, Muth, and Simon book was financed by the Office of Naval Research, which financed a lot of the Rand stuff and Arrow-Debreu stuff. And the hot item in business-school training was all this ... we were going to be management scientists. That's what we thought of ourselves doing; and Jack was a management scientist par excellence. That's just how he thought of himself. Marty Weingartner became president of the Institute of Management Science. Operations research was important; Arrow was important and involved in this stuff. That was a huge thing. And that's just dead now. You go into any business school now, and the last thing anybody wants to do is talk about mathematics, except in finance. 
Operations research is over. The students like we had, they were engineers just out of school. They didn't know how to tie a tie. We thought we were models for corporate America. \{laughter\} We wore suits. Modern MBA students are a totally different breed - they're smart guys, but they're totally different.

HOOVER: Earlier, when you were talking about the concept of rational expectations, everybody was treating it as one of those ideas that when you see it, you just see that it's right. It's like the invention of the button or something like that, even though it took a long time for people to come up with it. I'd like to quote from the introduction to Lucas and Sargent's famous anthology of articles on rational expectations [Lucas and Sargent 1981]. In the introduction, they write: "Muth's hypothesis is a contribution of the most fundamental kind, an idea that compels rethinking on many dimensions with consequent enthusiasm and resistance" [Lucas and Sargent 1981, p. xi] There's nothing we've heard so far that speaks at all to the resistance to rational expectations when it was first introduced to macroeconomics around 1970. I wonder if we can get the panel to speak a little bit about that resistance, holding yourself to the period of that first introduction in the 'seventies.

SHILLER: When I was a graduate student at MIT, I was writing under Franco Modigliani. I thought that the rational expectations was exciting, and so I wrote my dissertation, and it was titled "Rational Expectations and the Term Structure of Interest Rates." But I have to say that all along I had doubts about it. I guess that's healthy, right? Your minister will tell you that: it's healthy to have doubts. I applied it to the term structure of interest rates back then, because I thought that's where it's really going to work, because you've got all these professional portfolio managers, and 
they're managing bond portfolios. They're smart enough to do this, so I applied it there. But I did have doubts all along, and it led me on my own odyssey. In 1978, I wrote a critical review of rational expectations. It was kind of mixed. I hope that I didn't offend you, Bob ... you probably don't remember. I said something at the end about Bob Lucas, you know, something to the effect that we have to allow geniuses a little eccentricity sometimes. \{laughter\} Remember that Sir Isaac Newton believed in astrology or alchemy or something like that. It's a sign of a free spirit that you follow models along, but you're not going to be a success in every dimension. The concept of rational expectations is guaranteed not to be a complete success. I'll give you a more recent example that illustrates that to me. It's about the speculative bubble we've seen in the housing market. If you apply rational expectations to the housing demand, you would build an ARIMA model of home prices, and you would have people forecasting optimally. But when I got into this I found that you cannot possibly build an ARIMA model of home prices because there is no home price index - period. There's some garbage index, but you know that you can't trust that. That led me to create the S\&P Case-Shiller Home Price Index with my colleague Carl Case. Now we have data back to 1890 , and we can do time series analysis on that. But, funny thing, nobody wanted that data. I mean anyone could have built the index, but there was just no interest. So, there's something wrong with a rational-expectations model that poses people as building ARIMA models of home prices when there is no home price data. I'll stop with that. It works somewhere, and that's the challenge of economics. You have models that have a certain logic and accord in them, and they work in some 
applications; but there's always work for new graduate students, because they won't work everywhere.

HOOVER: Can you say something about resistances? What about the rest of you? You seemed to have been fighting a battle in the 'seventies, and nobody wants to tell war stories . . . \{laughter $\} \ldots$ but are there war stories to tell?

LUCAS: I'll tell one, and Bob Shiller's involved in it too. People thought rational expectations were associated with conservative policies. Tom [Sargent] and I and Bob Shiller were on some panel that talked about some government program that he didn't like. He said, "Tom, this should appeal to you, since it involves reducing the size of the government." So, Tom, who was at this point was a liberal Democrat, said, "well, I don't have any particular interest in reducing the size of government." Now, why did Bob think that? Because everyone just connected up . . maybe it was just Friedman' dominant influence. If you supported, say, Friedman's monetary policy, that meant you were a Friedmanite all the way down the line.

MORTENSEN: Or if you were in Hyde Park, you were tainted. \{laughter

LUCAS: Yeah or something. And now no one thinks rational expectations is going to support conservative policies across the board. I think we've gone past that idea. It doesn't mean you have to be in love with rational expectations, but it's getting divorced from the political thing - at least it should be.

SHILLER: That reminds me that Tom Sargent - I think it was Sargent, but maybe it was you - was asked by a reporter "What advice do you have for the Federal Reserve?" And he said, "Keep doing what you've been doing." Was that you or was 
that Tom? I have no idea. The point is that, whatever the policy rule is, as long as it is consistently applied, it has no effect. \{laughter\} I am sure that the reporter didn't understand it. $\{$ laughter $\}$

YOUNG: Just to put rational expectations into a broader intellectual context, at approximately the same time as rational expectations was gaining traction so was the efficient-markets hypothesis in finance. Although formally related, the two hypotheses seem to have different historical roots. Can you shed any light on how they were first connected? Do they stand or fall together?

LUCAS: Merton Miller was on both thesis committees. He was on Jack's committee at Carnegie Tech; and when he moved to Chicago, he was on Gene Fama's [Eugene Fama's] committee. So, I asked him that question once, and said, "we didn't see it." He knew both theses, but he didn't see that they were saying very similar things.

SHILLER: I have a lot to say about this. I put on my reading list a wonderful description of the efficient-markets hypothesis - by Charles Conant, 1904.. He has a beautiful essay about speculation and markets and the function of speculation and how all these speculators, trying to make profits, create a price, not just for today; they create a price for tomorrow and a price for next year and all relevant years in the futures markets. And, then, people who are planning have all these price indicators. It's laid out very nicely around 1910. He didn't call it the "efficient-markets hypothesis;" but it was a little glib too. Anyway, he never got famous for it. He was however a great writer. So, the efficient-markets hypothesis was well known from, I think, then on, if not before. And the next thing that happened, that seemed to me was a turning point, was that the Ford Foundation gave the University of Chicago a grant 
to create the Center for Research in Security Prices (CRSP) tapes in 1960. And this is another breakthrough They made an appeal to Ford about the importance to science of data; they got a large They said that all the data is sitting there in the vaults of the stock exchange, but nobody knows what it means. And they said, "let's create tapes" - a Univac computer tape (can you believe that?) - "and we'll give it away at cost to anybody. This is public domain. And what we are going to do is to organize all these stock price data. And let's get it clear, so we know the actual returns, the dividends, the timing, the dates. Let's get it all accurately and get it on a Fortran program, so that anybody can analyze it." That's the big turning point. By 1970 we had Gene Fama publishing an impressive review article about a huge body of research about market efficiency. But all of that happened because now for the first time, because before then nobody ever had stock price data. (Conant was just writing from personal experience and logic.) There was a little bit of commodities data and there was random-walk talk in the twenties and thirties, but now in the 1960s we had all the data back to 1926 . And it was analyzed, and the computers were working on it, and the results looked impressive. Basically, all these researchers couldn't find any consistent profit opportunities. It was just amazing. Again, the uniformity of these results was overstated by Gene Fama; but there was a breakthrough here - a breakthrough of science, of computers, of someone getting the data organized, and getting it available.

HOOVER: I'd like to go back and push you a little bit more on reception. It is pretty clear that some of the frisson associated with rational expectations in the early 'seventies arose from the association with Sargent and Wallace's policy- 
ineffectiveness idea and with Lucas's idea that the Phillips curve was ephemeral, that it was a product of informational asymmetries that couldn't be exploited effectively for policy purposes. I would like to know to what extent you think about the preferences for policy outcomes - different actors' preferences for policy outcomes contributed to the reception of rational expectations and to the debates and arguments about it. Maybe, Neil Wallace could go on this one first.

WALLACE: Well, I think, Bob's work on the Phillips curve, was enormously important. When Bob and I were graduate students at the University of Chicago, part or all of the final exam in Milton Friedman's course was a take-home project in which Friedman posed unsolved questions. At the end of the second semester, Friedman posed a Phillips-curve question: roughly speaking, how do you explain the Phillipscurve correlation? When I first went to the University of Minnesota as a faculty member in the fall of 1963 - very ill-educated and very naive - I raised that question with some of my macro colleagues--many of whom were educated at MIT. They were very surprised that someone would even ask that question. So, yes, Bob's work on expectations and neutrality was a huge thing that had to upset a lot of the profession. It was revolutionary in that substantive way, but it was also revolutionary in terms of modeling strategy. It's hard to overstate the sense in which it was revolutionary in that regard.

LOVELL: I'd like to answer your question in a slightly negative way. Jack Muth was not the first to develop the concept of rational expectations. He gave it a name, but the concept itself had been invoked by Herbert Simon in his 1956 certainty equivalence article and by Hans Theil in a related paper. Certainty equivalence is the proposition 
that you can, under certain restrictive conditions, including no non-negative constraints, find the optimal solution to a dynamic programming problem under uncertainty by solving a much simpler problem obtained by substituting point estimates for the probability distribution of possible future states of the world. By using the means of that distribution as certainty equivalents, you get the same set of optimal decisions as you would if you labored through the uncertainty problem. But in order to prove his theorem, Herb had to invoke the assumption that the expectation had certain stochastic properties, and these turn out to be the properties of rational expectations that became famous a few years later. So perhaps we should ask, why did the assumption of rational expectations not take hold sooner than it did since it was necessary to prove Simon's famous theorem. Herb didn't give it a name; and his explanation of the assumption he made was a little befuddled, but it was definitely there and it is definitely required for certainty equivalence to go through. And it is a symbiotic relationship because Herb's certainty equivalence underlies much of Muth's 1960 Econometrica article: Muth invoked Simon's certainty equivalence proposition to justify using the point-estimated form of rational expectations in a variety of applications, including his critique of the cobweb theorem.

LUCAS: The idea that there is no long-run Phillips curve is not mine; it's Friedman's and Phelps's. And I had a Phillips curve. Leonard Rapping and I worked out a model which we got a Phillips curve out of. And we did not apply rational expectations in that model. In fact, there was a long-run Phillips curve, if our model were true. We read Friedman's paper, which seemed to us right - it was just a conflict. A standard way to look at long-run effects in a difference-equation model that all of use were 
using at that point was to calculate the short-run, impact multiplier (as we used to call it), and the long-run multiplier, and look at the long-run multiplier: it was zero or it wasn't; it was whatever it was. And with Rapping's and my Phillips curve, it was a tradeoff. A lot of people tested - so-called - Friedman and Phelps ideas, and they all rejected it. So did we. This is just a fact of the data, if this was your test. So, what I was trying to do - and did - was to get out of that bind. For that, changing from adaptive expectations, which Rapping and I had used, to rational expectations did the trick and gave new life to the Friedman-Phelps argument. It was a question of evidence and how you interpret evidence, not just a question of which theory is the prettiest.

HOOVER: I want to follow up on this. You have a paper about 1970 - I think it was published a few years later - on the econometric testing of the natural rate hypothesis. Lucas 1972b]. And one of the interesting things about that paper - because now your position is “well, its all in Friedman; I didn't have that much of an innovation" - is, if I remember it correctly, that you used Friedman as your whipping boy: "Friedman talks about natural rate, but he doesn't really have a natural rate, because this thing never comes back to equilibrium because of the kind of expectations he assumed."

LUCAS: Friedman just had a pure theoretical model, and he didn't explain why all the econometricians disagreed with him - including me and Rapping. So, in the end, I think, in some sense, Friedman was right, but you've got to look at the evidence . . .

HOOVER: I am just suggesting that ...

LUCAS: and get some kind of story ... 
HOOVER: I think that at one point you might have claimed more innovation than you are willing to claim now.

LUCAS: No, there's plenty of innovation to go around \{laughter $\}$. . but the particular issue is no longer a Phillips curve ...

YOUNG: I would just like to wrap up the policy-impact part of the questions with a point that Alan Meltzer, another Carnegie personality, made very recently in his history of the Federal Reserve. Alan says that rational expectations had no significant impact on FOMC decision-making, although it had some impact on the Board of Governors model. Why do you think that rational expectations' policy impact was not as great as its academic impact? ... Neil, you were at the Minneapolis Fed, do you want to answer that?

WALLACE: When Mark Willes came to the Minneapolis Federal Reserve as president, he decided to publicize some of the research on rational expectations. In particular, Mark had the view that some of the policy-ineffectiveness stuff was something that deserved a hearing within the system. I have no opinion on whether he actually had an impact. I don't follow Fed policy closely. However, I wonder if there is much difference between Federal Reserve policy during the last thirty years and the previous thirty years.

YOUNG: A follow-up to Bob on this: In June of 1978 at the Boston Fed Conference, there seems to have been some resistance, at least, by some economists whom we all remember to a paper that you wrote with Tom, which was based on rational expectations. Talking about the war stories, can you - would you like to - tell us exactly what happened? I'm asking this because quite recently Mike Lovell pulled out 
of one of his boxes the contents of the NBER conference in March 1974 on rational expectations, which some of you attended and at which Neil's and Tom's paper in its original form was actually presented. Bob Shiller actually wrote the report on the conference. So, the question is trying to date when this freshwater/saltwater split, which was based more or less on rational expectations and the policy ineffectiveness or policy neutrality, as Neil called it, came about. Did it come about at the June 1978 Federal Reserve meeting in Boston, which is the conventional wisdom, or was it actually something that occurred a few years before?

LUCAS: The paper that Tom and I gave at that conference was badly written and I can't stand to reread it. The writing is mine. It's not a milestone in economic research . . . people woke up anyway, but ...

YOUNG: The question is, do you recall, going back to the 1974 conference, which Mike was at, which Bob was at, which Tom was at, and which you were at, do any of you recall what actually went down at this conference or was this something which Mike just discovered recently ...

WALLACE: . . . 36 years ago . . . \{laughter $\}$

YOUNG: No, the point I'm trying to make is that the policy neutrality is actually presented first there and do any of you recall any reaction that you may have had? I ask this because I also put the question to Ben Friedman. Ben, who gave a paper on rational expectations, says that he thinks that you can date whatever debate there was the academic debate - from the 1974 conference. So, does anybody have any insights into that? ... Nobody remembers it? 
LUCAS: I've been to a lot of conferences with the people's whose names you read out; you got to do better than that? Which paper was it? Was it Neil's and Tom's paper?

YOUNG: It was Neil and Tom's paper.

LUCAS: OK. Well, that was shocking. You take a model and do nothing but fiddle with the expectations thing and it completely alters the behavior. But it wasn't a model that either Tom or Neil would go to bat for as the right way to think about the U.S. economy ... at least that's how I think of it.

HOOVER: Warren was trying to push you on really fine-detailed microhistory. Historians take a really long perspective, and 36 years doesn't seem like much. But I'll shift it back to a broader question. The anthology that I mentioned before - the Lucas and Sargent anthology - was entitled Rational Expectations and Econometric Practice [Lucas and Sargent 1981]. The question is, how important was rational expectations to econometrics and how important was econometrics to rational expectations? Is the main contribution of rational expectations a contribution to economic theory or a contribution to econometrics?

LUCAS: Before rational expectations, a lot of people were formulating distributed lag models of expectations with a lot of free parameters. It was easy to rationalize these. Now, rational expectations just imposed that every free parameter you throw into the model is going to give you a testable hypothesis. So, all of sudden, you are going from a model which is more or less vacuous to a model which has eighteen restrictions and is not going to pass an $F$-test for anything. You go from acceptance to rejection. Sargent wrote a paper about the Fisher hypothesis on inflation expectations and interest rates, that the interest rate is driven by the expectation of all these future 
prices, which wasn't as tight as a term-structure test, and it had seemed to look pretty good for Fisher. But Sargent showed that when you impose all these restrictions implied by rational expectations, it just fails. This had a very big effect . . . it seemed like, all of a sudden, instead of macro being a thing where we could write down any damn model and claim that it was consistent with the data, it turned into a field in which anything that you wrote was going to get rejected right away. So, the way people were doing their testing and estimation changed a lot with rational expectations.

HOOVER: Can I get anyone else to comment on rational expectations and econometrics.

WALLACE: I would just say that rational expectations brought structural estimation into macro.

HOOVER: Then, by structural estimation you mean something different from the Cowles-Commission-inspired large macromodels of the 'fifties and'sixties.

WALLACE: Yeah, I guess I do.

HOOVER: Do you want to characterize that difference?

WALLACE: Well, it's about the standards you require in positing the underlying structure that generates the observation.

SHILLER: The core idea that underlies this is that people have tastes and technology and they have tradeoffs in their preferences. That's the underlying structure. We have to go from that to a macro model - and an intertemporal model where people live for a hundred years at least for a long time. If you start from that framework of optimizing 
your utility function, every decision you make depends on your expectation of every economic variable into the distant future. And when you think about it from that perspective, writing down some arbitrary model of the FRB-MIT variety doesn't sound exactly right because you are sweeping under the rug too much. ${ }^{5}$ Maybe that's what you were saying

HOOVER: Let me follow up on my question to make it more pointed so that Mike Lovell and others can comment on it. In 1986, Mike, you wrote a pretty well known paper in which you examined the empirical success of a variety of alternatives to rational expectations, including adaptive expectations, structural expectations, and implicit expectations [Lovell 1986]. And in your paper, rational expectations does not dominate these alternatives. You even cite a paper by Muth, which comes down more or less in favor of implicit expectations. What I am wondering, then, is that, given the way that you have approached this empirically or the way it could be approached empirically, does this mean that we should find an alternative to rational expectations or are there other expectational approaches that are an empirical complement to rational expectations?

LOVELL: I wish Jack Muth could be here to answer that question, but obviously he can't because he died just as Hurricane Wilma was zeroing in on his home on the Florida Keys. But he did send me a letter in 1984. This was a letter in response to an earlier draft of that paper you are referring to. I sent Jack my paper with some

\footnotetext{
${ }^{5}$ FRB-MIT (or FRB-MIT-Penn) refers to the Federal Reserve Board-Massachusetts Institute of Technology (University of Pennsylvania) econometric model of the U.S. economy (see inter alia DeLeeuw, and Gramlich 1968).
} 
trepidation because it was not encouraging to his theory. And much to my surprise, he wrote back. This was in October 1984. And he said,

I came up with some conclusions similar to some of yours on the basis of forecasts of business activity compiled by the Bureau of Business Research at Pitt. [Letter Muth to Lovell, 2 October 1984]

He had got hold of the data from five business firms, including expectations data, analyzed it, and found that the rational expectations model did not pass the empirical test. He went on to say

It is a little surprising that serious alternatives to rational expectations have never really been proposed. My original paper was largely a reaction against very naïve expectations hypotheses juxtaposed with highly rational decisionmaking behavior and seems to have been rather widely misinterpreted.

Two directions seem to be worth exploring: (1) explaining why smoothing rules work and their limitations and (2) incorporating well known cognitive biases into expectations theory (Kahneman and Tversky). It was really incredible that so little has been done along these lines.

Muth also said that his results showed that expectations were not in accordance with the facts about forecasts of demand and production. He then advanced an alternative to rational expectations. That alternative he called an "errors-in-thevariables" model. That is to say, it allowed the expectation error to be correlated with both the realization and the prediction. Muth found that his errors-in-variables model worked better than rational expectations or Mills' implicit expectations, but it did not entirely pass the tests. In a shortened version of his paper published in the Eastern Economic Journal Muth [1985, p 200] he reported:.

The results of the analysis do not support the hypotheses of the naive, exponential, extrapolative, regressive, or rational models. Only the expectations revision model used by Meiselman is consistently supported by the statistical results... These conclusions should be regarded as highly tentative and only suggestive, however, because of the small number of firms studied. 
Muth thought that we should not only have rational expectations, but if we're going to have rational behavioral equations, then consistency requires that our model include rational expectations. But he was also interested in the results of people who do behavioral economics, which at that time was a very undeveloped area.

HOOVER: Does anyone else want to comment on issue of testing rational expectations against alternatives and if it matters whether rational expectations stands up to empirical tests or whether it is not the sort of thing for which testing would be relevant?

SHILLER: What comes to my mind is that rational expectations models have to assume away the problem of regime change, and that makes them hard to apply. It's the same criticism they make of Kahnemann and Tversky, that the model isn't clear and crisp about exactly how you should apply it. Well, the same is true for rational expectations models. And there's a new strand of thought that's getting impetus lately, that the failure to predict this crisis was a failure to understand regime changes. The title of a recent book by Carmen Reinhart and Ken Rogoff - the title of the book is This Time is Different - to me invokes this problem of regime change, that people don't know when there's a regime change, and they may assume regime changes too often - that's a behavioral bias [Carmen Reinhart and Kenneth Rogoff 2009]. I don't know how we're going to model that. Reinhart and Rogoff haven't come forth with any new answers, but that's what comes to my mind now, at this point in history. And I don't know whether you can comment on it: how do we handle the regime change problem? If you don't have data on subprime mortgages then you build a model that doesn't have subprime mortgages in it. Also, it doesn't have the shadow banking sector in it 
either. Omitting key variables because we don't have the data history on them creates a fundamental problem That's why many nice concepts don't find their way into empirical models and are not used more. They remain just a conceptual model.

HOOVER: Bob, do you want to . . or Dale ...

MORTENSEN: More as a theorist, I am sensitive to that problem. That is the issue. If the world were stable, then rational expectations means simply agents learning about their environment and applying what they learned to their decisions. If the environment's simple, then how else would you structure the model? It's precisely if you like, call it "regime change" - what do you do with unanticipated events? More generally - regime changes is only one of them - you were talking about institutional change that was or wasn't anticipated. As a theorist, I don't know how to handle that.

HOOVER: Bob, did you want to comment on that? You're looking unhappy, I thought.

LUCAS: No. I mean, you can't read Muth's paper as some recipe for cranking out true theories about everything under the sun - we don't have a recipe like that. My paper on expectations and the neutrality of money was an attempt to get a positive theory about what observations we call a Phillip's curve. Basically it didn't work. After several years, trying to push that model in a direction of being more operational, it didn't seem to explain it. So we had what we call price stickiness, which seems to be central to the way the system works. I thought my model was going to explain price stickiness, and it didn't. So we're still working on it; somebody's working on it. I don't think we have a satisfactory solution to that problem, but I don't think that's a cloud over Muth's work. If Jack thinks it is, I don't agree with him. Mike cites some data that Jack couldn't make sense out of using rational expectations . . . There're a lot 
of bad models out there. I authored my share, and I don't see how that affects a lot of things we've been talking about earlier on about the value of Muth's contribution.

YOUNG: Just to wrap up the issue of possible alternatives to rational expectations or complements to rational expectations. Does behavioral economics or psychology in general provide a useful and viable alternative to rational expectations, with the emphasis on useful. \{laughter\}

SHILLER: Well that's the criticism of behavioral economics, that it doesn't provide elegant models. If you read Kahnemann and Tversky, they say that preferences have a kink in them, and that kink moves around depending on framing. But framing is hard to pin down. So we don't have any elegant behavioral economics models. The job isn't done, and economists have to read widely and think about these issues. I am sorry, I don't have a good answer. My opinion is that behavioral economics has to be on the reading list. Ultimately, the whole rationality assumption is another thing; it's interesting to look back on the history of it. Back at the turn of the century - around 1900 - when utility-maximizing economic theory was being discovered, it was described as a psychological theory - did you know that, that utility maximization was a psychological theory? There was a philosopher in 1916 - I remember reading, in the Quarterly Journal of Economics - who said that the economics profession is getting steadily more psychological. ${ }^{6}$ \{laughter $\}$ And what did he mean? He said that economists are putting people at the center of the economy, and they're realizing that people have purposes and they have objectives and they have trade-offs. It is not just that I want something, I'll consider different combinations and I'll tell you what I like

\footnotetext{
${ }^{6}$ Perry (1916).
} 
about that. And he's saying that before this happened, economists weren't psychological; they believed in such things as gold or venerable institutions, and they didn't talk about people. Now the whole economics profession is focused on people. And he said that this is a long-term trend in economics. And it is a long-term trend, so the expected utility theory is a psychological theory, and it reflects some important insights about people. In a sense, that's all we have, behavioral economics; and it's just that we are continuing to develop and to pursue it. The idea about rational expectations, again, reflects insights about people - that if you show people recurring patterns in the data, they can actually process it - a little bit like an ARIMA model and they can start using some kind of brain faculties that we do not fully comprehend. They can forecast - it's an intuitive thing that evolved and it's in our psychology. So, I don't think that there's a conflict between behavioral economics and classical economics. It's all something that will evolve responding to each other - psychology and economics.

LUCAS: I totally disagree.

MORTENSEN: I think that we've come back around the circle - back to Carnegie again. I was a student of Simon and [Richard] March and [James] Cyert and March in fact, I was even a research assistant on A Behavioral Theory of the Firm [Cyert and March 1963]. So, we talked about that in those days too. I am much less up on modern behavioral economics. However, I think what you are referring to are those aspects of psychology that illustrate the limits, if you like, of perception and, say, cognitive ability. Well, Simon did talk about that too - he didn't use those precise words. What I do see on the question of expectations - right down the hall from me - 
is my colleague Chuck Manksi [Charles Manksi] and a group of people that he's associated with. They're trying to deal with expectations of ordinary people. For a lot of what we are talking about in macroeconomics, we're thinking of decision-makers sure that they have all the appropriate data and have a sophisticated view about that data. You can't carry that model of the decision-maker over to many household decisions. And what's coming out of this new empirical research on expectations is precisely that: how do people think about the uncertainties that go into deciding about what their pension plan is going to look like. I think that those are real issues, where behavioral economics, in that sense, can make a very big contribution to what the rest of us do.

LUCAS: One thing economics tries to do is to make predictions about the way large groups of people, say, 280 million people are going to respond if you change something in the tax structure, something in the inflation rate, or whatever. Now, human beings are hugely interesting creatures; so neurophysiology is exciting, cognitive psychology is interesting - I'm still into Freudian psychology - there are lots of different ways to look at individual people and lots of aspects of individual people that are going to be subject to scientific study. Kahnemann and Tversky haven't even gotten to two people; they can't even tell us anything interesting about how a couple that's been married for ten years splits or makes decisions about what city to live in let alone 250 million. This is like saying that we ought to build it up from knowledge of molecules or - no, that won't do either, because there are a lot of subatomic particles - . . we're not going to build up useful economics in the sense of things that help us think about the policy issues that we should be thinking about starting from 
individuals and, somehow, building it up from there. Behavioral economics should be on the reading list. I agree with Shiller about that. A well trained economist or a well educated person should know something about different ways of looking at human beings. If you are going to go back and look at Herb Simon today, go back and read Models of Man. But to think of it as an alternative to what macroeconomics or public finance people are doing or trying to do ... there's a lot of stuff that we'd like to improve - it's not going to come from behavioral economics. . . at least in my lifetime. \{laughter

HOOVER: We have a couple of questions to wrap up the session. Let me give you the next to last one: the Great Recession and the recent financial crisis have been widely viewed in both popular and professional commentary as a challenge to rational expectations and to efficient markets. I really just want to get your comments on that strain of the popular debate that's been active over the last couple years.

LUCAS: If you're asking me did I predict the failure of Lehmann Brothers or any of the other stuff that happened in 2008 , the answer is no.

HOOVER: No, I'm not asking you that. I'm asking you whether you accept any of the blame. $\{$ laughter $\}$ The serious point here is that, if you read the newspapers and political commentary and even if you read commentary among economists, there's been a lot of talk about whether rational expectations and the efficient-markets hypotheses is where we should locate the analytical problems that made us blind. All I'm asking is what do you think of that?

LUCAS: Is that what you get out of Rogoff and Reinhart? You know, people had no trouble having financial meltdowns in their economies before all this stuff we've been 
talking about came on board. We didn't help, though; there's no question about that. We may have focused attention on the wrong things; I don't know.

SHILLER: Well, I've written several books on that. \{laughter\} My latest is with George Akerlof is called Animal Spirits [2009]. And we presented an idea that Bob Lucas probably won't like. It was something about the Keynesian concept. Another name that's not been mentioned is John Maynard Keynes. I suspect that he's not popular with everyone on this panel. Animal Spirits is based on Keynes. He said that animal spirits is a major driver of the economy. To understand Keynes, you have to go back to his 1921 book, Treatise on Probability [Keynes 1921]. He said - he's really into almost this regime-change thing that we brought up before - that people don't have probabilities, except in very narrow, special circumstances. You can think of a coin-toss experiment, and then you know what the probabilities are. But in macroeconomics, it's always fuzzy. What Keynes said in The General Theory [1936] is that, if people are really thoroughly rational, they would be paralyzed into inaction, because they just don't know. They don't know the kind of things that you would need to put into a decision-theory framework. But they do act, and so there is something that drives people - it's animal spirits. You're lying in bed in the morning and you could be thinking, "I don't know what's going to happen to me today; I could get hit by a truck; I just will stay in bed all day. But you don't. So animal spirits is the core of - maybe I'm telling this too bluntly - . . but it fluctuates. Sometimes it is represented as confidence, but it is not necessarily confidence. It is trust in each other, our sense of whether other people think that we're moving ahead or ... something like that. I believe that's part of what drives the economy. It's in our book, and it's not 
very well modeled yet. But Keynes never wrote his theory down as a model either. He couldn't do it; he wasn't ready. These are ideas that, even to this day, are fuzzy. But they have a hold on people. I'm sure that Ben Bernanke and Austin Goolsbee are influenced by John Maynard Keynes, who was absolutely not a rational-expectations theorist. And that's another strand of thought. In my mind, the strands are not resolved, and they are both important ways of looking at the world.

HOOVER: Anyone else want to comment on this?

MORTENSEN: I have a certain sympathy for that. I've been asked why are we stuck in the mud in the labor market. If you look at the data, what happened was unemployment doubled in a year, and it didn't do that for structural reasons. It obviously did that because all of a sudden expectations changed. And expectations, as far as I can see, haven't changed back. So, I have some sympathy . . . I happen to also to be a fan of that particular chapter of The General Theory. Keynes also said that it was the fluctuation of those expectations that was the main source of the trade cycle. He didn't explain the fluctuations in expectations. So, the notion of expectations shocks, though unscientific, are hard to just dismiss out of hand.

WALLACE: You won the Nobel Prize at a bad time. \{laughter\}

YOUNG: We want to start wrapping up and talk about the significance and future of rational expectations. Looking back over the past 50 years, how would you assess the overall significance of rational expectations? And what do you see as the role of rational expectations in the future development of economics? In 50 years, will rational expectations still be the essential element in economists' tool kit? 
MORTENSEN: I'll venture a prediction: it'll be around in 50 years.

LUCAS: It may be around under a different name. Like I say, Kreps and Wilson talk . .

MORTENSEN: . . . you can't do without it . . .

LUCAS: . . as seriously about dynamic games in a recursive way, and they don't use the term.

WALLACE: Well, yeah, I can't imagine doing economics without this. Rational expectations models people as being in touch with the world that they are living in. It's probably politically incorrect, but one definition of insanity is that you're not in touch. So, I don't know what else to do.

LOVELL: The answer depends in part on what definition you give of "rational expectations." So, I suspect that if you want to predict the future you will have to ask Thomas Kuhn.

SHILLER: Ok, I'm willing to bet that 50 years from now we will still be talking about rational expectations. [Thomas] Kuhn talks about scientific revolutions throwing out theories. This is not a theory that's going to be completely thrown out. It is might be deemphasized, but it's, as you say, an equilibrium concept and a basic modeling technique that is applicable in certain circumstances. And we'll still be debating - I won't be - but in 50 or 100 years we'll still have the same tensions. We have different competing models that each has its own life. They each capture something, and they capture it imperfectly. Economics is not an exact science. We're never going to resolve that one of them is right and that one of them is wrong. 
HOOVER: Well, gentlemen, thank you very much. \{Applause

\section{References}

Akerlof, George A. and Robert J. Shiller. (2009) Animal Spirits: How Human Psychology Drives the Economy, and Why It Matters for Global Capitalism. Princeton: Princeton University Press.

Blizard William and Joseph Warner. (1780) "A New Method of Treating the Fistula Lachrymalis," Philosophical Transactions of the Royal Society of London 70, pp. 239245

Box, George and Gwilym Jenkins. (1970) Time Series Analysis: Forecasting and Control. San Francisco: Holden-Day.

Conant, Charles A. (1904) Wall Street and the Country: A Study of Recent Financial Tendencies. New York: Putnam.

Cyert, Richard M. and James G. March. (1963) A Behavioral Theory of the Firm. Englewood Cliffs, NJ: Prentice-Hall.

DeLeeuw, Frank and Edward Gramlich (1968) "The Federal Reserve-MIT Econometric Model," Federal Reserve Bulletin 54(1), 11-40.

Fama, Eugene. (1970) "Efficient Capital Markets: A Review of Theory and Empirical Work," Journal of Finance 25(2), 383-418.

Holt, Charles C., Franco Modigliani, John F. Muth, and Herbert A. Simon. (1960). Planning Production, Inventories, and Work Force. Englewood Cliffs, NJ: Prentice Hall:

Keynes, John Maynard. (1921) Treatise on Probability. London: Macmillan.

Keynes, John Maynard. (1936) The General Theory of Employment Interest and Money. London: Macmillan.

Lovell, Michael C. (1986) "Tests of the Rational Expectations Hypothesis," American Economic Review 76(1), 110-124.

Lucas, Robert E., Jr. (1972a). "Expectations and the Neutrality of Money," Journal of Economic Theory 4 (2), 103-124.

Lucas, Robert E., Jr. (1972b) "Econometric Testing of the Natural Rate Hypothesis," in Otto Eckstein, editor. The Econometrics of Price Determination Conference. Washington, D.C.: Board of Governors of the Federal Reserve System, pp. 50-59.

Lucas, Robert E., Jr. (1981) and Thomas J. Sargent, editors. Rational Expectations and Econometric Practice. London: Allen and Unwin.

Markowitz, Harry M. (1952) “Portfolio Selection,” Journal of Finance 7(1), 77-91. 
Mills, Edwin S. (1962) Price, Output and Inventory Policy. New York: John Wiley.

Muth, John F. (1960). "Optimal Properties of Exponentially Weighted Forecasts," Journal of the American Statistical Association, 55(290), 299-306.

Muth, John F. (1961) "Rational Expectations and the Theory of Price Movements," Econometrica 29(3), 315-335

Perry, Ralph B. (1916) "Economic Value and Moral Value," Quarterly Journal of Economics 30(3), 443-485.

Price, L. L. (1923) “Industrial Policy,” Economic Journal 33(131), pp. 352-361

This Time Is Different: Eight Centuries of Financial Folly. Princeton : Princeton University Press.

Robinson, Joan. (1951) “The Rate of Interest,” Econometrica 19(2), 92-111.

Sargent, Thomas J. and Neil Wallace. (1971) Journal of Money, Credit and Banking 3(2, Part 2), 469-505

Schelling, Thomas C. (1958) "The Strategy of Conflict Prospectus for a Reorientation of Game Theory," Journal of Conflict Resolution 2(3), 203-264. 